\title{
Progesterone induces apoptosis of insulin-secreting cells: insights into the molecular mechanism
}

\author{
V A Nunes ${ }^{1,+}$, E P Portioli-Sanches ${ }^{2}$, M P Rosim ${ }^{2}$, M S Araujo 3 , P Praxedes-Garcia 3 , \\ M M R Valle ${ }^{2}$, LP Roma ${ }^{2}$, C Hahn ${ }^{4}$, E Gurgul-Convey ${ }^{4}$, S Lenzen ${ }^{4}$ and A K Azevedo-Martins ${ }^{1}$ \\ ${ }^{1}$ School of Arts, Sciences and Humanities and ${ }^{2}$ Institute of Biomedical Sciences, University of Sao Paulo, \\ Sao Paulo, Brazil \\ ${ }^{3}$ Department of Biochemistry of Federal University of Sao Paulo, Sao Paulo, Brazil \\ ${ }^{4}$ Institute of Clinical Biochemistry, Hannover Medical School, Hannover, Germany \\ ${ }^{t} \mathrm{~V}$ A Nunes is now at School of Arts, Sciences and Humanities, Avenida Arlindo Bettio, \\ 1000, 03828-000 Sao Paulo, SP, Brazil
}

Correspondence should be addressed to $V$ A Nunes

Email

vanunes@ib.usp.br

\begin{abstract}
Progesterone has been associated with the development of gestational diabetes (GD) due to the enhancement of insulin resistance. As $\beta$-cell apoptosis participates in type 1 and type 2 diabetes pathophysiology, we proposed the hypothesis that progesterone might contribute to the development of GD through a mechanism that also involves $\beta$-cell death. To address this question, RINm5F insulin-producing cells were incubated with progesterone (25-100 $\mu \mathrm{M})$, in the presence or absence of $\alpha$-tocopherol $(40 \mu \mathrm{M})$. After 24 or $48 \mathrm{~h}$, membrane integrity and DNA fragmentation were analyzed by flow cytometry. Caspase activity was used to identify the mode of cell death. The involvement of endoplasmic reticulum stress in the action of progesterone was investigated by western blotting. Oxidative stress was measured by $2^{\prime}, 7^{\prime}$-dichlorofluorescein diacetate (DCFDA) oxidation. Isolated rat islets were used in similar experiments in order to confirm the effect of progesterone in primary $\beta$-cells. Incubation of RINm5F cells with progesterone increased the number of cells with loss of membrane integrity and DNA fragmentation. Progesterone induced generation of reactive species. Pre-incubation with $\alpha$-tocopherol attenuated progesterone-induced apoptosis. Western blot analyses revealed increased expression of CREB2 and CHOP in progesteronetreated cells. Progesterone caused apoptotic death of rat islet cells and enhanced generation of reactive species. Our results show that progesterone can be toxic to pancreatic $\beta$-cells through an oxidative-stress-dependent mechanism that induces apoptosis. This effect may contribute to the development of GD during pregnancy, particularly under conditions that require administration of pharmacological doses of this hormone.
\end{abstract}

\author{
Key Words \\ - insulin-producing cells \\ - progesterone \\ - oestriol \\ - apoptosis \\ - oxidative stress \\ - gestational diabetes
}

\section{Introduction}

The steroid hormones progesterone and the oestrogens have been shown to be involved in $\beta$-cell physiology, exerting direct effects on insulin secretion (for review see Lenzen \& Bailey (1984) and Straub et al. (2001)) and islet cell proliferation (Kawai \& Kishi 1999, Nieuwenhuizen et al. 1999, Le May et al. 2006) through binding to their specific receptors (Pasanen et al. 1997, Le May et al. 2006). In addition, Picard et al. (2002) suggested that 
the hormonal particularities of pregnancy, and more specifically progesterone, might contribute to the poor adaptation of insulin secretion (Straub et al. 2001) and action to the increased requirements during pregnancy.

In the pregnancy scenario, the diabetogenic effect of progesterone has been mostly explained by the enhancement of insulin resistance (Butte 2000), particularly in skeletal muscle and adipose tissue, through a reduction in glucose transporter 4 (GLUT4 (SLC2A4)) expression (Sugaya et al. 2000). However, considering that apoptosis is involved in the pathophysiology of type 1 and 2 diabetes and also contributes to the involution of the $\beta$-cell mass in the postpartum phase (Scaglia et al. 1995), we first proposed the hypothesis that progesterone might be involved in $\beta$-cell death, also contribute to the development of gestational diabetes (GD). Both progesterone's diabetogenic effect and its potential to induce $\beta$-cell death require attention with the increasing pharmacological use of progestagens throughout pregnancy for prevention of recurrent preterm delivery (Sanchez-Ramos et al. 2005, Dodd et al. 2008, Jayasooriva \& Lamont 2009), which has been correlated to the enhanced incidence of GD (Rebarber et al. 2007).

Little is known about the possible mechanisms by which progesterone exerts its effects on $\beta$-cells; however, studies have shown that this hormone is able to modulate the generation of reactive oxygen species (ROS) and oxidative stress in different cell types (Nguyen \& Syed 2011, Toyoda et al. 2011). Thus, as the pancreatic $\beta$-cells present very low activities of antioxidant enzymes (Tiedge et al. 1997) and it has been observed that the overexpression of these enzymes protects these cells against diabetogenic insults (Lortz et al. 2000, Azevedo-Martins et al. 2003, Gurgul et al. 2004), we considered that progesterone might act through an oxidative-stressdependent mechanism that has been recognised as a stimulus for endoplasmic reticulum (ER) stress and for the unfolded protein response (UPR) (Cao \& Kaufman 2012).

In contrast to the effects of progesterone, data from human and animal studies indicate that $17 \beta$-estradiol (estradiol) prevents a decrease in insulin production in the diabetic state (Le May et al. 2006). Also, estradiol, at pharmacological concentrations, protects human pancreatic islets from apoptosis induced by proinflammatory cytokines in vitro (Contreras et al. 2002). This information led us to consider that an antidiabetic action of estradiol might be due, at the least in part, to prevention of $\beta$-cell apoptosis. Therefore we also evaluated the effect of oestriol, the major oestrogen produced during pregnancy, on progesterone-induced cell death.
We report herein that progesterone, at pharmacological concentrations, as used for preterm delivery prevention, induced apoptosis of RINm5F insulin-producing cells and rat islet cells, which could be almost abolished by pre-incubation with $\alpha$-tocopherol. Cell death induced by progesterone was enhanced by oestriol, though this oestrogen per se had only little effect. In RINm5F insulinproducing cells, the ER stress-related proteins CCAAT/ enhancer-binding protein homologous protein (CHOP) (DDIT3) and CREB2 (CRTC2) were differentially expressed following exposure to progesterone, indicating that ER stress leading to an accumulation of unfolded/misfolded proteins may contribute to the observed effects.

\section{Materials and methods}

\section{Materials}

RPMI-1640 medium, HEPES, penicillin and streptomycin were purchased from Invitrogen. Propidium iodide (PI) was purchased from ICN Biomedicals (Costa Mesa, CA, USA), sodium citrate from Merck and sodium bicarbonate from Labsynth Products (Diadema, SP, Brazil). The antibodies used were as follows: anti-CREB-2 and anti-CHOP (GADD 153) purchased from Santa Cruz Biotechnology, Inc. Thapsigargin was from Tocris (Bristol, UK). The ECL Western Blotting Analysis System kit was from Amersham Biosciences UK Limited. All cell culture plastic material was from Corning (Corning, NY, USA). Progesterone, oestriol and $\alpha$-tocopherol as well as $2^{\prime}, 7^{\prime}$-dichlorofluorescein diacetate (DCFDA) were from Sigma-Aldrich.

\section{Cell culture conditions and islet isolation}

RINm5F insulin-producing cells were cultured in RPMI1640 medium, containing $11.1 \mathrm{mM}$ glucose and $10 \%(\mathrm{v} / \mathrm{v})$ FCS. The medium was supplemented with $2.0 \mathrm{mM}$ glutamine, $20 \mathrm{mM}$ HEPES, $100 \mu \mathrm{g} / \mathrm{ml}$ streptomycin, $100 \mathrm{IU} / \mathrm{ml}$ penicillin and $24 \mathrm{mM}$ sodium bicarbonate. The cells were maintained in an incubator (Forma, ThermoScientific, Asheville, NC, USA) in a humidified atmosphere at $37^{\circ} \mathrm{C}$ and $5 \% \mathrm{CO}_{2}$.

Pancreatic islets were isolated from 3-month-old Wistar rats as described previously (Lenzen et al. 1983). The islets were washed and handpicked under a stereomicroscope. After an overnight culture, the islets were distributed into three batches and cultured at $37^{\circ} \mathrm{C}$ in RPMI-1640 medium containing $10 \mathrm{mM}$ glucose and $10 \%$ FCS with 0,25 or $100 \mu \mathrm{M}$ progesterone for $48 \mathrm{~h}$ and were used in the subsequent experiments. The islets for caspase

Published by Bioscientifica Ltd.

Downloaded from Bioscientifica,com at $04 / 26 / 2023$ 12:29:30AM via free access 
3 activation and DCFDA oxidation determination were cultured on ECM-coated dishes for 10-14 days until formation of monolayer, and thereafter incubated with the test compounds then analysed.

\section{Cell treatments}

The cells were seeded the day before treatments into sixwell plates for flow cytometric analyses $\left(8 \times 10^{5}\right.$ cells/well). Alternatively, pooled rat islets or rat islet-dispersed cells were used. Different concentrations of progesterone and/or oestriol were tested for 24 or $48 \mathrm{~h}$. In order to evaluate the effect of $\alpha$-tocopherol, the cells were preincubated for $2 \mathrm{~h}$ with this vitamin at a final concentration of $40 \mu \mathrm{M}$, before addition of progesterone. The hormones, $\alpha$-tocopherol and thapsigargin were dissolved in absolute ethanol. The final concentration of ethanol in the medium did not exceed $0.5 \%$. Staurosporine was diluted in DMSO. Ethanol and DMSO, used as vehicles, did not affect the experimental results.

\section{Cell proliferation assay}

The effect of progesterone on cell proliferation was evaluated by using the BrdU In situ Detection kit (BD Bioscience, Heidelberg, Germany) according to the manufacturer's protocol. Briefly, the cells were seeded onto Nunc LabTek II CC2 chamber slides (Fisher Scientific, Schwerte, Germany), treated with test compounds and fixed overnight with fixation buffer. After fixation, the cells were washed three times with PBS for $5 \mathrm{~min}$, followed by BrdU staining. Slides were thereafter mounted with Mowiol (Merck) plus 0.6\% Dabco (St Louis, MO, USA). Images were captured and analysed using a Cell ${ }^{\mathrm{R}} / \mathrm{Olympus}$ BX61 inverted microscope system (Olympus, Hamburg, Germany). BrdU-negativity and BrdU-positivity were determined for 200-500 cells in each experiment. Four independent experiments were carried out. Data are expressed as the percentage of BrdU-positive cells for each treatment condition.

\section{Cell membrane integrity assay}

The cells were centrifuged at $400 \boldsymbol{g}$ for $5 \mathrm{~min}$ at $4{ }^{\circ} \mathrm{C}$ and the pellet obtained was suspended in $500 \mu \mathrm{l}$ PBS. Thereafter, $50 \mu$ l PI solution ( $50 \mu \mathrm{g} / \mathrm{ml}$ in PBS) were added and the cells were analysed using a FACScalibur flow cytometer (Becton Dickinson, San Juan, CA, USA) (Nicoletti et al. 1991). Fluorescence was measured using the FL2 channel (orange-red fluorescence $585 / 42 \mathrm{~nm}$ ). A total of 10000 events were analysed per experiment. The cells with PI fluorescence were evaluated by using the Cell Quest software (Becton Dickinson).

For cell death evaluation of islets, after $48 \mathrm{~h}$ incubation with progesterone, rat pancreatic islets were disrupted by tryptic digestion and gentle pipetting. Living, apoptotic and dead cells were identified using the Guava ViaCount assay (Millipore, Billerica, MA, USA) based on the cytoplasmic and nuclear staining by two dyes. A membrane-permeant dye stained all nucleated cells, whereas a membrane-impermeant dye stained only damaged cells, thus indicating apoptotic and dying cells. Briefly, the cell suspensions were incubated with the ViaCount reagent for $5 \mathrm{~min}$ at room temperature. Data acquisition was carried out using a Guava EasyCyte flow cytometer (Millipore) and data analysis using the ViaCount software module.

\section{DNA fragmentation assay}

Apoptotic cells were evaluated by DNA fragmentation and loss of nuclear DNA content assays using the fluorochrome PI (Nicoletti et al. 1991). After trypsinisation, the cells were collected and incubated with a solution containing $0.1 \%$ Triton X-100. After incubation, the cells were centrifuged at $400 \mathrm{~g}$ for $5 \mathrm{~min}$ at $4{ }^{\circ} \mathrm{C}$. The pellet was gently added to $300 \mu \mathrm{l}$ hypotonic solution, containing $50 \mu \mathrm{g} / \mathrm{ml} \mathrm{PI,} 0.1 \%$ sodium citrate and $0.1 \%$ Triton X-100. The cells were then incubated overnight at $4{ }^{\circ} \mathrm{C}$ and analysed by flow cytometry.

Islet cell apoptosis detection was carried out by using the Cell Death Detection ELISA PLUS kit (Roche Diagnostics), according to manufacturer's instructions, which is based on the measurement of the amount of histoneassociated DNA fragments (mono- and oligonucleosomes). After cultivation of islets for $48 \mathrm{~h}$ in the presence of 0,25 or $100 \mu \mathrm{M}$ progesterone, batches of 80 islets were lysed in $100 \mu \mathrm{l}$ lysis buffer, and the cytosolic and nuclear fractions were separated by centrifugation at $200 \boldsymbol{g}$ for $10 \mathrm{~min}$. The mean absorbance at $405 \mathrm{~nm}$ of each sample was normalised using the DNA content in the nuclear fraction, using a positive control available in the kit. Experiments were carried out three times in duplicates.

\section{Determination of oxidative and nitrosative species generation}

Cells $\left(2 \times 10^{4}\right)$ were seeded onto 96-well black plates and pre-incubated with $10 \mu \mathrm{M}$ dichlorofluorescein diacetate (DCF-DA) for $30 \mathrm{~min}$ at $37^{\circ} \mathrm{C}$. The medium containing the reagent was discarded, and fresh medium with different

Published by Bioscientifica Ltd 
concentrations of progesterone was added. The cells were cultured for 6,12 and $24 \mathrm{~h}$. After incubation, the plates were analysed at $\lambda_{\mathrm{exc}}=480$ and $\lambda_{\mathrm{em}}=520 \mathrm{~nm}$ using the fluorescence reader Victor2 1420 Multilabel Counter (Perkin Elmer, Wiesbaden, Germany). Data were normalised to the number of viable cells and expressed as arbitrary units of DCF fluorescence.

For determination of oxidative stress by DCF fluorescence, rat islet cells were seeded onto ECM-coated dishes and pre-incubated wit $10 \mu \mathrm{M}$ DCFDDA for $60 \mathrm{~min}$ at $37^{\circ} \mathrm{C}$, followed by treatment with 25 or $100 \mu \mathrm{M}$ progesterone for $48 \mathrm{~h}$. Thereafter the cells were trypsinised and analysed using a CyFlow ML cytometer (Exc. 488 nm/Em. $520 \mathrm{~nm}$ ) (Partec, Münster, Germany). A total of 10000 events were counted. Data were analysed using FlowJo software (Tree Star, Ashland, OR, USA).

The superoxide content in islets was evaluated by flow cytometry (Guava EasyCyte, EMD Millipore Corporation, Billerica, MA, USA) through its reaction with hydroethidine (DHE), which generates the fluorescent product hydroxyethidium (Molecular Probes, Life Technologies, Carlabad, CA, USA) (Zhao et al. 2005). Batches of 30 islets were preincubated for $30 \mathrm{~min}$ at $37^{\circ} \mathrm{C}$ in Krebs-Henseleit solution (KH), pH 7.4 containing $10 \mathrm{mM}$ glucose. After this period, DHE was added at a final concentration of $50 \mu \mathrm{M}$. The samples, protected from light, were then incubated for an additional 20 min at room temperature. The islets were disrupted by trypsin and gentle pipetting and resuspended in $200 \mu \mathrm{l}$ RPMI-1640 medium. A set of 5000 events was evaluated per sample, and the yellow fluorescence was measured using an excitation wavelength of $488 \mathrm{~nm}$. The emission signal was acquired with the yellow filter $(583 \pm 26 \mathrm{~nm})$. The experiments were done in triplicates on three different days.

\section{Caspase activity determination}

Caspase activity in cell lysates was determined by fluorimetric assay using the substrate Abz-DEVDGVQEDDnp, as previously described by Nunes et al. (2005). Substrate $(20 \mu \mathrm{M})$ hydrolysis was determined in $25 \mathrm{mM}$ HEPES buffer, pH 7.4, containing $2.0 \mathrm{mM}$ EDTA, $10 \mathrm{mM}$ dithiothreitol, $10 \%$ sucrose, $0.1 \%$ 3-((3-cholamidopropyl)dimethylammonio)-1-propanesulfonate, $10 \mu \mathrm{g} / \mathrm{ml}$ pepstatin A, $10 \mu \mathrm{g} / \mathrm{ml}$ leupeptin and $100 \mu \mathrm{M}$ phenylmethylsulphonyl fluoride (PMSF) (caspase buffer), at $\lambda_{\mathrm{exc}}=320$ and $\lambda_{\mathrm{em}}=420 \mathrm{~nm}$ and for $3 \mathrm{~h}$ at $37^{\circ} \mathrm{C}$ in a microtiter plate Synergy Biotek (BioTek Instruments, Inc Winooski, VT, USA). Enzyme activity was expressed as arbitrary units of fluorescence (AUF) per microgram of protein. All determinations were carried out in triplicates in, at least, three individual experiments. Caspase activity was confirmed by incubating cell lysates with the caspase inhibitor Z-VAD-fmk (0.1 or $1 \mathrm{mM})$. Z-VAD-fmk efficiency was tested using purified recombinant caspase 3 , as described by Nunes et al. (2003, 2005).

\section{Discriminating specific caspase activity}

Specific activities of caspases 3, 9 and 12 were determined after $24 \mathrm{~h}$ of incubation with various concentrations of progesterone, using red caspase 3 and green caspases 9 and 12 staining kits (PromoCell, Heidelberg, Germany) according to the instruction manual. After staining and washing, cell suspensions and dispersed islet cells were immediately subjected to analysis using a CyFlow ML cytometer (Partec). A total of 20000 events were acquired. The number of cells with caspase activity was normalised to the number for untreated cells. Data were analysed by FlowJo software (Tree Star). A cytokine mixture consisting of $60 \mathrm{U} / \mathrm{ml} \mathrm{IL} 1 \beta, 185 \mathrm{U} / \mathrm{ml}$ TNF $\alpha$ and $14 \mathrm{U} / \mathrm{ml}$ IFN $\gamma$ (PromoCell) was used as positive control.

\section{Western blotting}

For western blotting experiments, the cells were lysed with 25 mM HEPES, pH 7.4, containing 0.5\% Triton X-100 and a cocktail of protease inhibitors (100 $\mu \mathrm{M}$ PMSF, $10 \mu \mathrm{g} / \mathrm{ml}$ leupeptin, $10 \mu \mathrm{g} / \mathrm{ml}$ pepstatin, $5 \mathrm{mM}$ EDTA). Homogenates were centrifuged at $12000 \mathrm{~g}$ for $10 \mathrm{~min}$ and the supernatants were collected. The protein concentration was determined according to the method described by Bradford (1976), using BSA as the standard. Aliquots with $50 \mu \mathrm{g}$ protein were freeze-dried, dissolved in $15 \mu \mathrm{l}$ of sample buffer (300 mM Tris, pH 7.2, 2\% SDS, 20\% glycerol, 1.2\% bromophenol blue and $3 \% \beta$-mercaptoethanol) and boiled for $7 \mathrm{~min}$. Extracted proteins were separated by 12\% PAGE and electrotransferred onto nitrocellulose membranes (GE Healthcare, Little Chalfont, Buckinghamshire, UK) for $2 \mathrm{~h}$ at $0.35 \mathrm{~A}$ at $4{ }^{\circ} \mathrm{C}$. The membranes were blocked with $5 \%$ non-fat milk in $10 \mathrm{mM}$ Tris buffer, $\mathrm{pH} 7.5,150 \mathrm{mM} \mathrm{NaCl}$ and $0.1 \%$ Tween 20 (TBS-T) for $2 \mathrm{~h}$ and subsequently incubated with MABs anti-CREB-2 (1:200) and anti-CHOP (1:200). After an overnight incubation with the primary antibodies at $4{ }^{\circ} \mathrm{C}$, the membranes were washed three times with TBS-T for $10 \mathrm{~min}$. The HRP-conjugated anti-goat secondary antibody (anti IgG-HRP) was incubated at $1: 1500$ for $1 \mathrm{~h}$ at room temperature. $\beta$-tubulin was used as a loading and transfer control in all experiments. Bound proteins were visualised using a commercially available chemiluminescence kit (ECL, GE Healthcare) according to

Published by Bioscientifica Ltd 
the manufacturer's instructions. The membranes were then exposed to autoradiography films (Kodak), which were developed and scanned. Densitometric analyses were carried out using the freeware program CP Atlas 2.0 (lazarsoftware.com). Western blots representative of three independent experiments are shown.

\section{Statistical analysis}

Results are expressed as mean \pm s.E.M. Statistical analyses were carried out using one-way ANOVA followed by Tukey's test for multiple comparisons using the Prism analysis program (Graphpad, San Diego, CA, USA).

\section{Results}

\section{Effects of progesterone on proliferation of insulin-producing cells}

Incubation of RINm5F insulin-producing cells for $24 \mathrm{~h}$ with progesterone did not affect cell proliferation significantly (Fig. 1A). After a $48 \mathrm{~h}$ incubation, a significant decrease in proliferation of insulin-producing cells was observed in the case of a high concentration of $100 \mu \mathrm{M}$, which is a concentration in the pharmacological range (Fig. 1A).

\section{Effects of progesterone on death of insulin-producing and rat islets cells}

Incubation of RINm5F cells with progesterone resulted also in a loss of cell membrane integrity at concentrations ranging from 50 to $100 \mu \mathrm{M}$ as shown in Fig. 1B. The effect was more pronounced after $48 \mathrm{~h}$ than after $24 \mathrm{~h}$ of incubation. About $60 \%$ of cells lost membrane integrity after $24 \mathrm{~h}$ and $90 \%$ after $48 \mathrm{~h}$ of incubation with $100 \mu \mathrm{M}$ progesterone. Staurosporine was used as a positive control for apoptotic cell death (Fig. 1B).

Progesterone also induced significant DNA fragmentation at a concentration range of $25-100 \mu \mathrm{M}$ in RINm5F cells (Fig. 1C). This effect was significantly stronger after $48 \mathrm{~h}$ comparing with after $24 \mathrm{~h}$ of incubation with the hormone (Fig. 1C).

In addition to our experiments using RINm5F cells as a model cell line for $\beta$-cells, we also carried out key experiments with islet cells. In general, rat islet cells presented a similar response to progesterone treatment. As shown in Table $1,100 \mu \mathrm{M}$ progesterone induced apoptotic death of dispersed islet cells after $48 \mathrm{~h}$ incubation. This effect was specific because the rate of
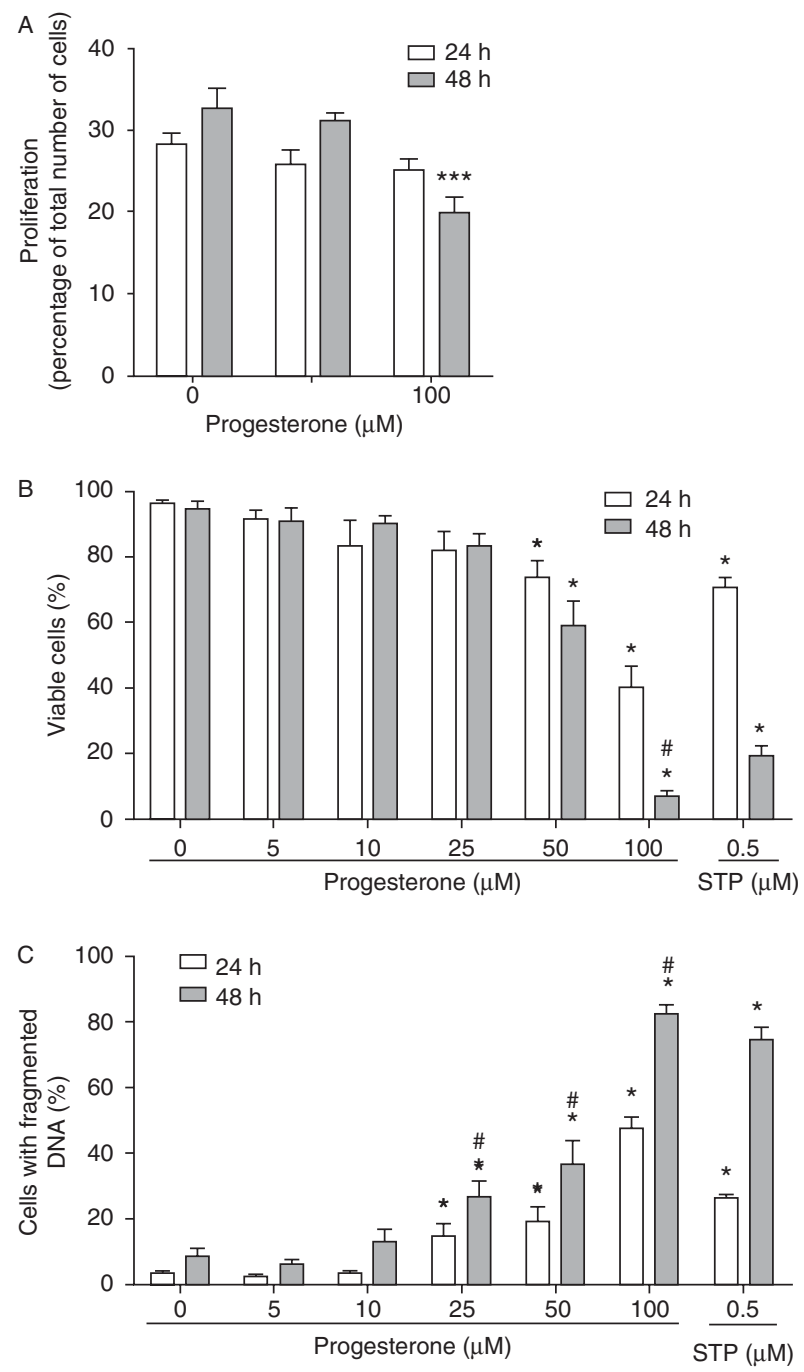

Figure 1

Concentration-dependent toxic effects of progesterone in RINm5F insulinproducing cells after 24 or $48 \mathrm{~h}$ of incubation. After incubation with progesterone, (A) cell proliferation; (B) cell membrane integrity and (C) DNA fragmentation were analysed. Data are presented as mean \pm S.E.M. of four to five experiments in triplicates. Differences were analysed for statistical significance by ANOVA followed by Tukey's test; ${ }^{*} P<0.05$ compared with untreated cells, $* * * P<0.01, P<0.05$ compared with the same treatment for $24 \mathrm{~h}$. STP, staurosporine.

nonapoptotic cell death was not affected by progesterone treatment (Table 1). Progesterone at a final concentration of $25 \mu \mathrm{M}$ did not cause a significant induction of cell death. The apoptotic nature of cell death was confirmed by detection of DNA internucleosomal cleavage in islet cells incubated with $100 \mu \mathrm{M}$ progesterone for $48 \mathrm{~h}$ (Fig. 2A). The amount of mono- and oligonucleosomes was almost 20fold higher in this group in comparison with the control group (Fig. 2A). Moreover, the measurement of caspase 3 
Table 1 Effect of progesterone on rat islet cell death. $P<0.05$.

\begin{tabular}{|c|c|c|c|}
\hline $\begin{array}{l}\text { Progesterone } \\
(\mu \mathrm{M})\end{array}$ & Viable & Apoptotic & $\begin{array}{c}\text { Dead } \\
\text { (non-apoptotic) }\end{array}$ \\
\hline 0 & $92.2 \pm 1.4$ & $4.3 \pm 1.0$ & $3.5 \pm 0.5$ \\
\hline 25 & $90.7 \pm 1.2$ & $4.6 \pm 0.9$ & $4.7 \pm 0.5$ \\
\hline 100 & $74.4 \pm 4.9 *$ & $19.0 \pm 3.7^{*}$ & $6.6 \pm 1.4$ \\
\hline
\end{tabular}

activity revealed a significant induction of this pathway by $100 \mu \mathrm{M}$ progesterone after a $48 \mathrm{~h}$ incubation (Fig. $2 \mathrm{~B}$ ).

\section{Effect of oestriol on viability of RINm5F $\beta$-cells}

Oestriol was much less toxic to RINm5F cells than progesterone. After incubation for 24 , as well as for $48 \mathrm{~h}$, oestriol caused a significant reduction in cell viability (25\%) only at the highest concentration $(100 \mu \mathrm{M})$ (Fig. 3A). Incubation of cells with $25 \mu \mathrm{M}$ oestriol and $100 \mu \mathrm{M}$ progesterone strongly enhanced the loss of cell membrane integrity at both time points.

Oestriol $(5-50 \mu \mathrm{M})$ did not cause significant DNA fragmentation after 24 or $48 \mathrm{~h}$ of incubation (Fig. 3B). Only the highest concentration of $100 \mu \mathrm{M}$ caused a slight significant increase in the number of cells with fragmented DNA (Fig. 3B). The toxic effect of progesterone $(100 \mu \mathrm{M})$ was significantly potentiated by oestriol $(25 \mu \mathrm{M})$ (Fig. 3B).

\section{Looking for the mechanisms by which progesterone induced cell death}

We evaluated the effect of progesterone in promoting caspase activation in RINm5F cells. Treatment of cells with progesterone resulted in a concentration-dependent increase in caspase activity as an indicator of apoptotic cell death (Fig. 4). Progesterone increased the activities of caspases 9, 12 and 3 (Fig. 5).

In order to investigate the effect of progesterone on generation of ROS, we used a fluorescence assay based on DCFDA oxidation. Significant production of ROS was observed after $12 \mathrm{~h}$ of incubation with $100 \mu \mathrm{M}$ progesterone and after $24 \mathrm{~h}$ with $50 \mu \mathrm{M}$ (Fig. 6). Similar effects were observed in dispersed rat islet cells, showing a significant induction of ROS formation after a $48 \mathrm{~h}$ incubation with $100 \mu \mathrm{M}$ progesterone (Fig. 7A). We also evaluated the effect of progesterone on formation of superoxide radicals in disrupted islets cells of rat. Progesterone at a final concentration of $100 \mu \mathrm{M}$ caused a significant enhancement of superoxide radical production, which was not evident with $25 \mu \mathrm{M}$ progesterone (Fig. 7B).
In the following experiments, we investigated the potential protective effect of the dietary antioxidant $\alpha$-tocopherol $(40 \mu \mathrm{M})$ against progesterone toxicity. This treatment reversed cell membrane integrity loss (Fig. 8A) and DNA fragmentation (Fig. 8B) of RINm5F cells. At concentrations of progesterone up to $50 \mu \mathrm{M}$, the toxic effect was abolished and, even at the highest progesterone concentration of $100 \mu \mathrm{M}, \alpha$-tocopherol $(40 \mu \mathrm{M})$ strongly counteracted the toxic effect of progesterone after both 24 and $48 \mathrm{~h}$ of incubation.

To investigate the participation of proteins and transcription factors involved in the UPR on progesterone-induced cell death, we evaluated the expression,
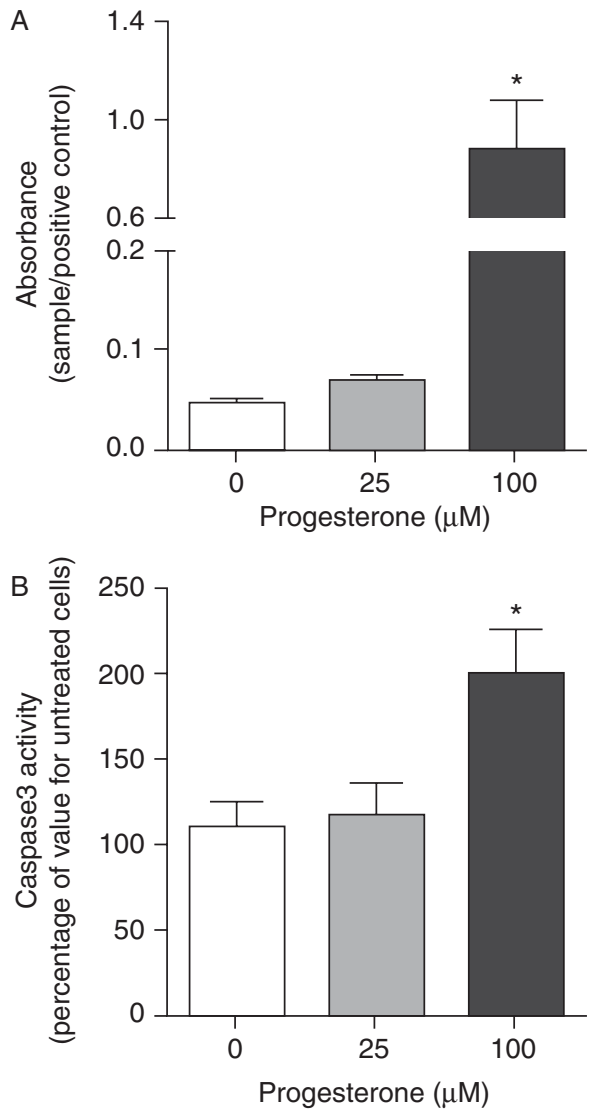

Figure 2

Effects of progesterone on islet cell apoptosis. After $48 \mathrm{~h}$ of treatment with progesterone, batches of 80 rat islets were (A) lysed and the presence of mono- and oligonucleosomes in the cytosolic fraction was evaluated by using the Cell Death Detection ELISA PLUS kit; (B) trypsinised, and incubated with a staining kit and caspase 3 activation was measured by flow cytometry. (A) The mean absorbance of each sample was normalised to that of the positive control provided in the kit and corrected for differences in islet DNA content of the nuclear fraction. (B) Data were normalised to the value for untreated cells. Data are presented as mean \pm s.E.M. of four experiments made in duplicate. Differences were analysed for statistical significance by ANOVA followed by Tukey's test; ${ }^{\star} P<0.05$ vs untreated.

Published by Bioscientifica Ltd 

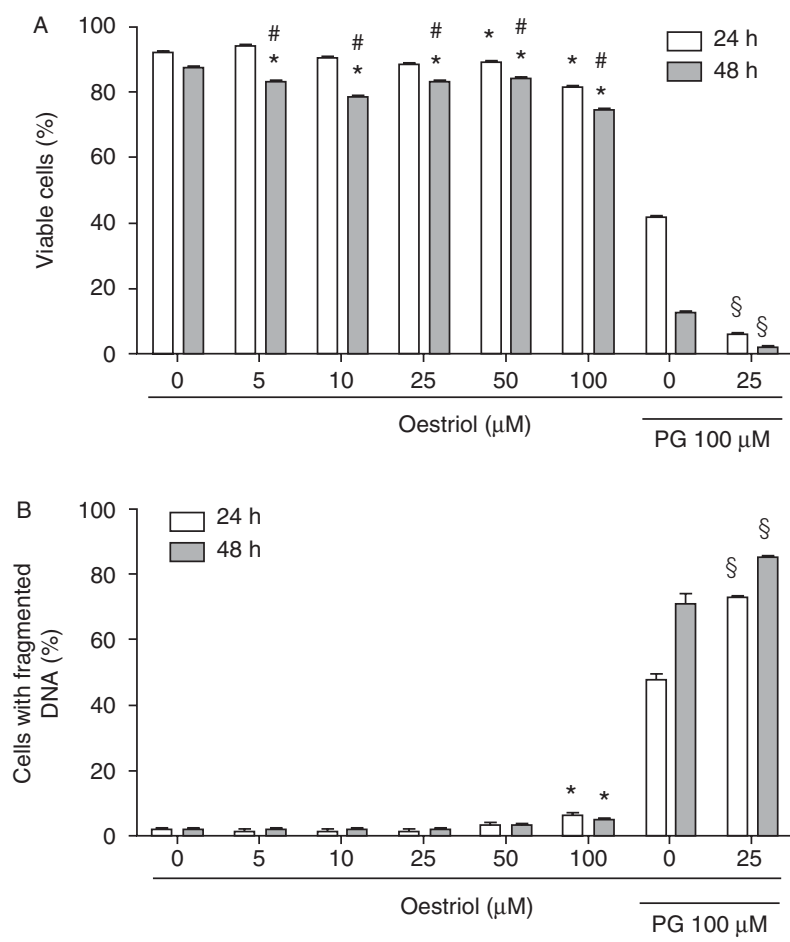

Figure 3

Concentration-dependent toxic effects of oestriol and progesterone (PG) in RINm5F insulin-producing cells after 24 or $48 \mathrm{~h}$ of incubation. After incubation with test compounds, (A) cell membrane integrity and (B) DNA fragmentation were analysed. Cells were incubated with progesterone and/or oestriol at different concentrations for 24 or $48 \mathrm{~h}$. Data are presented as mean \pm s.E.M. of three to four experiments in triplicates. Differences were analysed for statistical significance by ANOVA followed by Tukey's test; $* P<0.05$ compared with untreated cells, ${ }^{\#} P<0.05$ compared with the same treatment for $24 \mathrm{~h},{ }^{5} P<0.05$ compared with treatment with progesterone alone at the same time point.

by western blotting, of CHOP and cAMP-response element-binding protein 2 (CREB2, also called ATF4). Thapsigargin, an inhibitor of sarcoplasmic/ER $\mathrm{Ca}^{2+}$ ATPases (SERCAs), which pumps $\mathrm{Ca}^{2+}$ into the ER (Nakagawa et al. 2000), was used as a positive control of ER stress, at concentrations that were able to induce cell death as assessed by flow cytometry (data not shown).

Our findings showed a concentration-dependent increase in the expression of CHOP and CREB2 after incubation of cells with progesterone (Fig. 9). Densitometric analyses revealed that CHOP expression (Fig. 9A) was sixfold and tenfold higher after incubation with 25 and $100 \mu \mathrm{M}$ progesterone, respectively, in comparison with untreated cells, when normalised to $\beta$-tubulin expression (Fig. 9A). These effects were observed at both time points ( 24 and $48 \mathrm{~h}$ ) and expression was increased even more after the longer incubation period.
The CREB2 protein level in cells incubated with 25 or $100 \mu \mathrm{M}$ progesterone was 2.7 times higher than that for untreated cells (Fig. 9B). After $48 \mathrm{~h}$ of incubation with the same progesterone concentrations, an increase in CREB2 expression of 1.8- and 1.2-fold was observed, in comparison with treatment for $24 \mathrm{~h}$. Oestriol alone did not affect CREB2 expression. However, in combination with $100 \mu \mathrm{M}$ progesterone for $48 \mathrm{~h}$, the amount of this protein was increased compared with cells treated with progesterone alone (Fig. 9B).

\section{Discussion}

Although the diabetogenic potency of progesterone is well-known (for review, see Lenzen \& Bailey (1984) and Butte (2000)), the present study provides new insights into the mechanisms of its direct action on insulin-producing cells under conditions that require pharmacological use of this hormone, such as for prevention of recurrent preterm delivery. Accordingly, it seems especially relevant to evaluate the potential effects of progesterone-based medications on mother and foetus. Considering the diabetogenic effect of progesterone, Rebarber et al. (2007) reported that the use of $17 \alpha$-hydroxyprogesterone caproate (17P), in the micromolar range, by women having a history of preterm delivery, increased the risk of development of GD. Another study involving women of hispanic descent with no previous history of diabetes showed that the use of an injectable progestagen-based contraceptive for long periods of time was associated with an increased

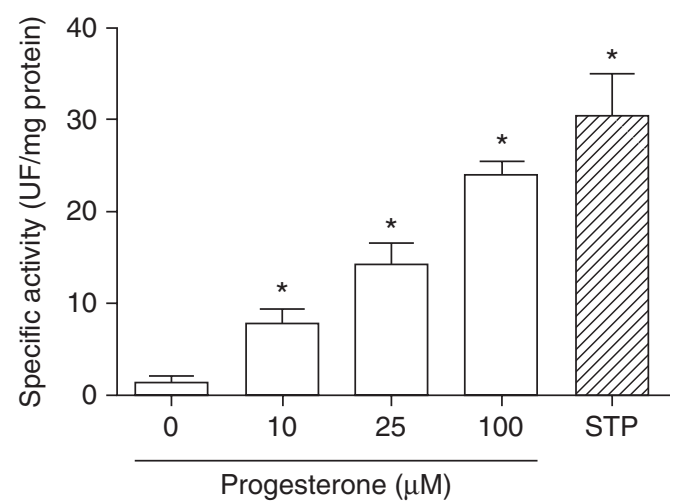

Figure 4

Concentration-dependent effects of progesterone on caspase activities of RINm5F insulin-producing cells after $24 \mathrm{~h}$ of incubation. Results were expressed as arbitrary units of fluorescence (UF) per minute per milligram of cytosolic protein. Data are presented as mean \pm s.E.M. of triplicates of three separate experiments. Differences were analysed for statistical significance by ANOVA followed by Tukey's test; $* P<0.05$ different from untreated cells. STP, staurosporine.

Published by Bioscientifica Ltd 
A

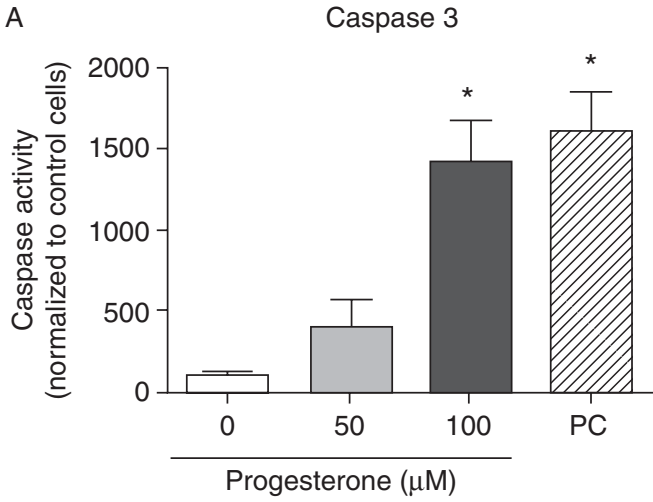

B

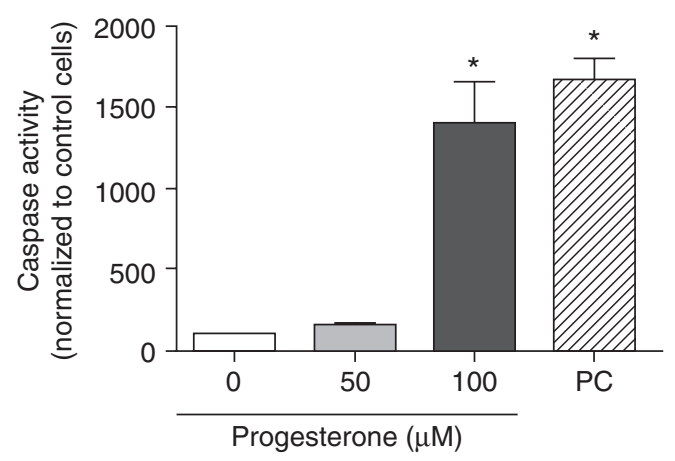

C

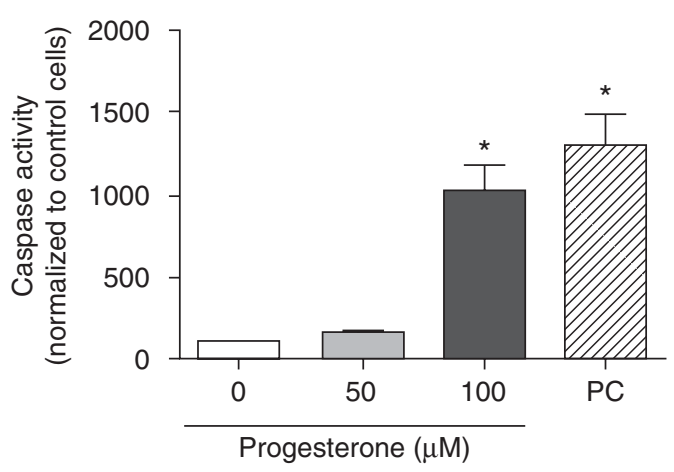

Figure 5

Concentration-dependent effects of progesterone on caspases 3, 9 and 12 activities in RINm5F insulin-producing cells after $24 \mathrm{~h}$ of incubation. Data were normalised to values for control cells and expressed as mean \pm s.E.M. of triplicates of three separate experiments. Differences were analysed for statistical significance by ANOVA followed by Tukey's test; * $P<0.05$ vs untreated. PC, positive control (cytokine mixture).

risk of developing GD (Xiang et al. 2006). Though another group did not find a correlation between progesterone use and an increasing risk of GD (Gyamfi et al. 2009), we have demonstrated in this study a direct effect of this hormone on the pancreatic $\beta$-cell line, RINm5F, and on rat islet cells causing apoptotic cell death, at concentrations ranging from 50 to $100 \mu \mathrm{M}$ which correspond to the pharmacological concentrations currently used for the prevention of preterm delivery (Dodd et al. 2008).

It is well-known that during development of diabetes $\beta$-cells undergo apoptosis, causing impairment of insulin production and secretion. In this study, we showed that exposure of both insulin-producing cells and rat islets to progesterone resulted in caspase activation and DNA fragmentation, confirming the occurrence of apoptosis. Moreover, we could show that progesterone at high micromolar concentrations was able also to decrease the proliferation rate of insulin-producing cells.

Studies investigating progesterone as a death inducer using other cell types are controversial. Candolfi et al. (2005) showed that progesterone is able to antagonise the apoptosis induced by TNF $\alpha$ in somatotrophs and lactotrophs. On the other hand, Cheng et al. (2006) obtained the opposite results using hepatoma HuH-7 cells, indicating that the beneficial or deleterious effects of this hormone may be tissue-specific. Though the mechanism of progesterone cytotoxicity is not completely clarified, the ability of progesterone to induce oxidative stress has been investigated (Verma \& Rana 2008).

In fact, it has been shown that ROS and redoxdependent mechanisms can affect the process of apoptosis (Sen 1998). A relationship between ROS and apoptosis is supported by many experimental findings (Jabs 1999, Wei et al. 2000), and studies have reported that antioxidants can suppress or delay apoptosis by acting as scavengers of ROS in different systems (Zamzami et al. 1995).

We have shown that progesterone caused an augmentation of oxidative species generation in both RINm5F insulin-producing cells and rat islets, which may be related

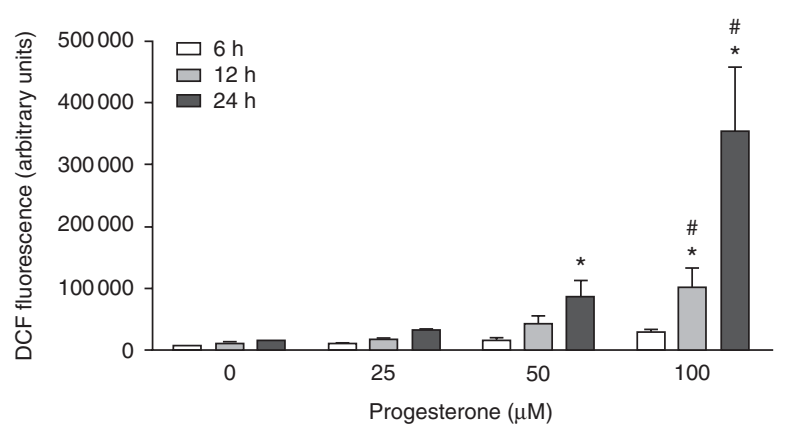

Figure 6

Concentration-dependent effects of progesterone on reactive oxygen species (ROS) generation in RINm5F insulin-producing cells after 6, 12 or $24 \mathrm{~h}$ of incubation as measured by the increase in DCF fluorescence. Data are presented as mean \pm s.E.M. of three experiments in triplicates. Differences were analysed for statistical significance by ANOVA followed by Tukey's test; ${ }^{*} P<0.05$ compared with untreated cells, ${ }^{\#} P<0.05$ compared with the $50 \mu \mathrm{M}$ dose at the same time point. http://joe.endocrinology-journals.org DOI: 10.1530/JOE-13-0202
() 2014 Society for Endocrinology Printed in Great Britain 

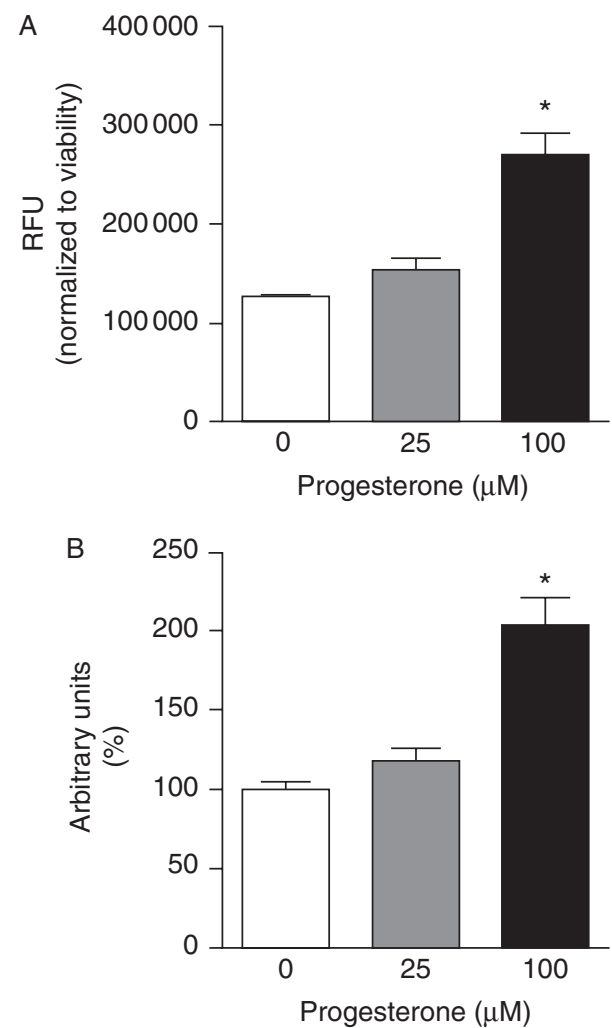

\section{Figure 7}

Effects of progesterone on oxidative stress and superoxide radical formation in rat islets. For measurement of overall oxidative stress (A) dispersed rat islet cells were preincubated with DCF-DA $(10 \mu \mathrm{M})$ for $60 \mathrm{~min}$, followed by incubation with progesterone for $48 \mathrm{~h}$. For superoxide radical detection (B) cells were first treated for $48 \mathrm{~h}$ with progesterone followed by incubation with DHE $(50 \mu \mathrm{M})$ for $20 \mathrm{~min}$, and then dispersed using trypsin and gentle pipetting, and resuspended in $200 \mu \mathrm{l} \mathrm{RPMI-1640} \mathrm{medium.} \mathrm{A} \mathrm{set}$ of 5000 (DHE) to 10000 (DCF) events were evaluated per sample by flow cytometry. Data are presented as mean \pm S.E.M. of three to four experiments in triplicates. Differences were analysed for statistical significance by ANOVA followed by Tukey's test; $* P<0.05$ vs untreated.

to the mechanisms by which progesterone exerts its effects on pancreatic $\beta$-cells.

Supporting the idea that antioxidants can suppress apoptosis induced by progesterone and based on the fact that pancreatic $\beta$-cells are very sensitive to redox changes (Lenzen 2008), which correlated with their low antioxidant enzyme activity (Tiedge et al. 1997), we found that $\alpha$-tocopherol, a natural antioxidant, reduced or even abolished progesterone toxicity in insulin-producing cells, resulting in both reduced rates of cell death and small percentages of cells with fragmented DNA. However, we could show that oestriol, the main oestrogen in pregnancy (Reyes et al. 2006), was not able to protect $\beta$-cells against progesterone-induced cell death, as originally proposed. Rather, this hormone alone was able to induce cell death, when used at concentrations up to $25 \mu \mathrm{M}$, although it was much less toxic than progesterone. Furthermore, our results showed that oestriol is able to slightly enhance the effect of progesterone on RINm5F cell death.

The oxidative imbalance has been also recognised as a stimulus for ER stress, which affects the ability of the cells to properly fold proteins, and plays an important role in pancreatic $\beta$-cell death (Oyadomari \& Mori 2004, Wu \& Kaufman 2006, Eizirik \& Cnop 2010).

A number of mechanisms have been proposed for connecting ER stress to apoptotic cell death, including the direct activation of proteases (Nakagawa et al. 2000, Momoi 2004), kinases (Ito et al. 2001), transcription factors, Bcl-2-family proteins and their modulators (Wei et al. 2001, Scorrano et al. 2003). Therefore, with certain stimuli, the activation of different signal transduction cascades takes
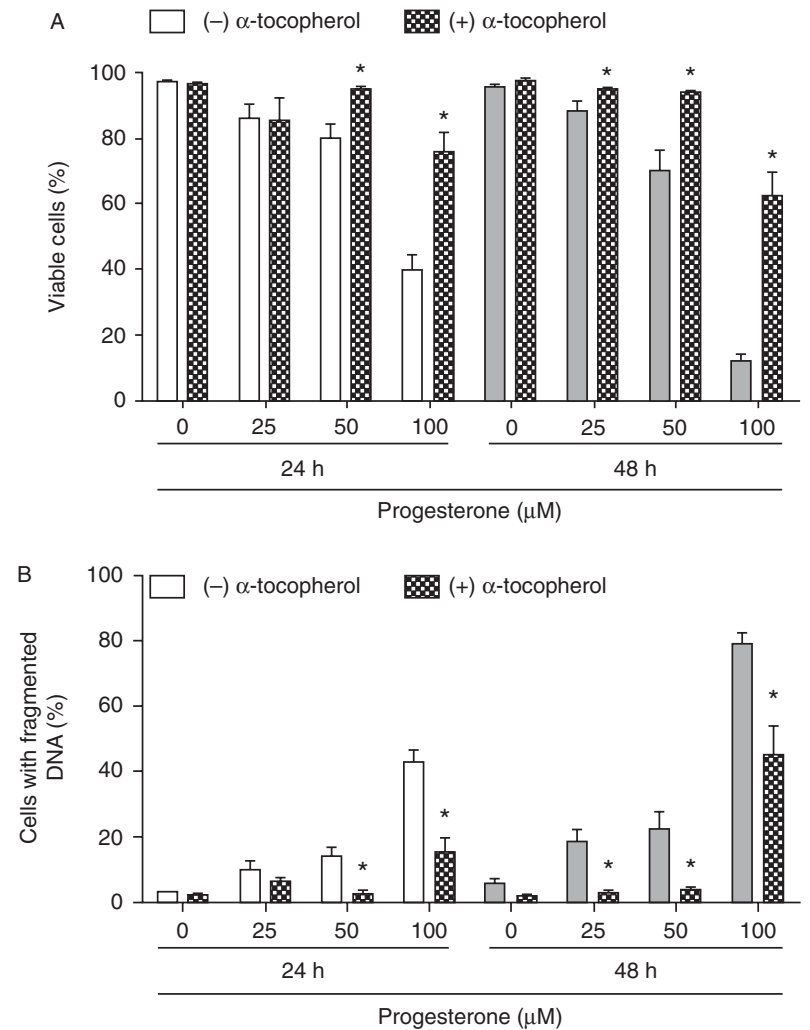

Figure 8

Protective effect of $\alpha$-tocopherol $(40 \mu \mathrm{M})$ against progesterone-induced membrane integrity loss and DNA fragmentation in RINm5F insulinproducing cells after 24 or $48 \mathrm{~h}$ of incubation. After incubation, (A) cell membrane integrity; (B) DNA fragmentation were analysed. Cells were preincubated for $2 \mathrm{~h}$ with $\alpha$-tocopherol before incubation with progesterone for 24 or $48 \mathrm{~h}$ at different concentrations. Data are presented as mean \pm S.E.M. of four experiments in triplicates. Differences were analysed for statistical significance by ANOVA followed by Tukey's test; * $P<0.05$ compared with PG treatment alone. 


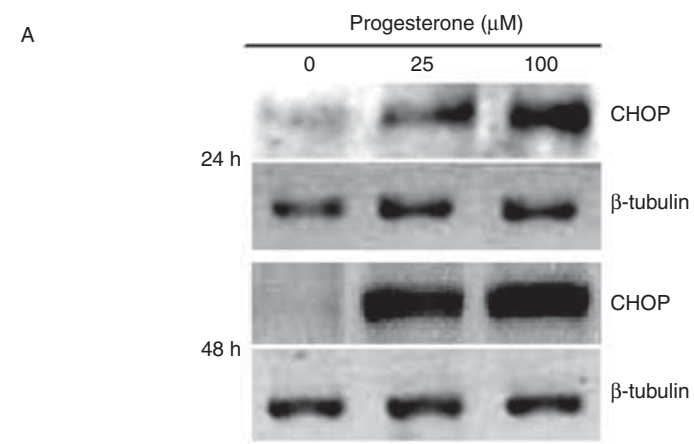

B
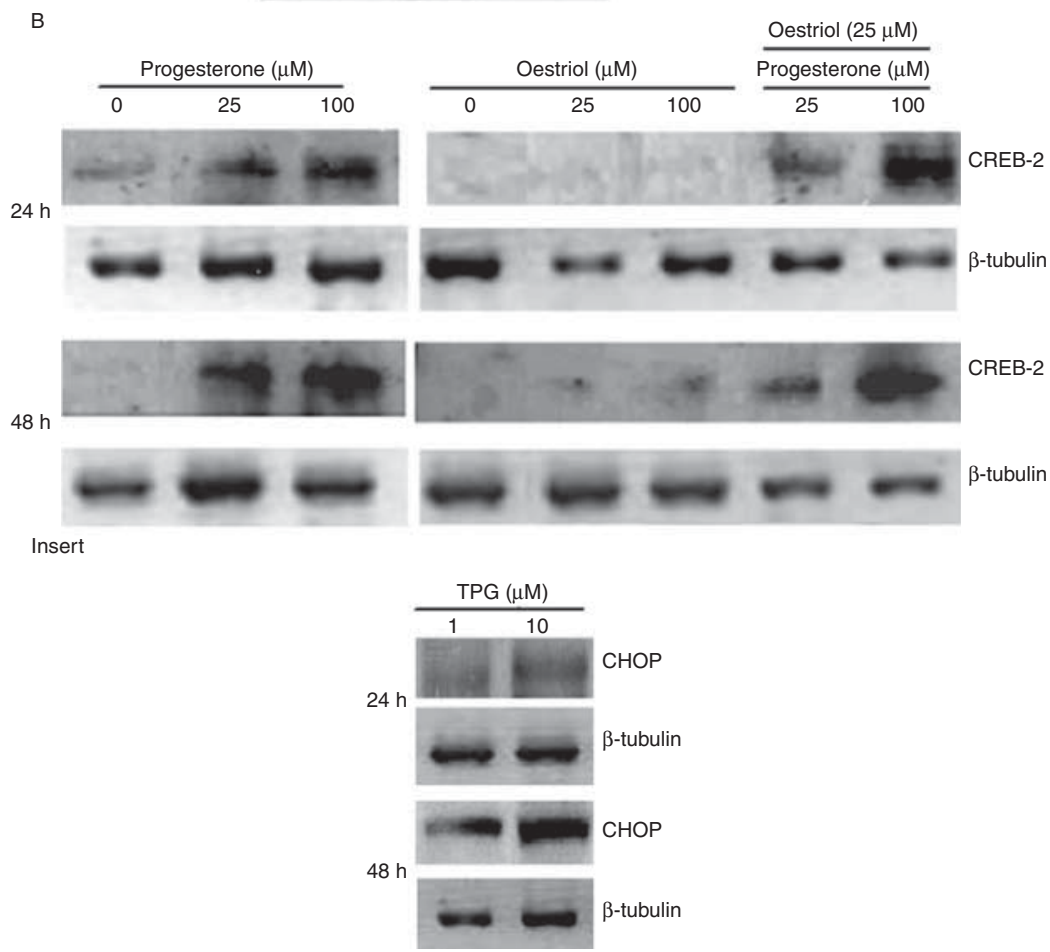

Figure 9

Immunodetection of proteins involved in UPR in progesterone and/or oestriol-treated RINm5F insulin-producing cells after 24 or $48 \mathrm{~h}$ of incubation. Cells were incubated with progesterone and/or oestriol or with thapsigargin (TPG) at different concentrations for 24 or $48 \mathrm{~h}$. Western blots representative of three independent experiments for (A) CHOP and (B)

place in the ER lumen, collectively called the UPR. The UPR, which initially acts to counteract toxicity, can eventually trigger cell death if ER dysfunction is severe or prolonged (Rao et al. 2001). In this perspective, proteins downstream of all UPR pathways have been identified as having proapoptotic functions. An example is the proapoptotic protein $\mathrm{CHOP}$, which is upregulated by the transcription factor activating transcription factor 4 (ATF4 or CREB2), and exclusively responsive to ER stress (Welihinda \& Kaufman 1996). CHOP causes downregulation of the anti-apoptotic mitochondrial protein BCL2 (Yoshida et al. 1998), favouring a proapoptotic pathway involving proteins that promote mitochondrial
CREB-2 are depicted. For both proteins, cells were treated for 24 and $48 \mathrm{~h}$. This figure is composed of images of different gels, where samples of progesterone and oestriol-treated cells were run in the same experiment at each time point. $\beta$-tubulin expression was used as a loading control. Thapsigargin was used as a positive control for ER stress.

damage, cytochrome $c$ release and caspase 3 activation (Matsumoto et al. 1996, Allagnat et al. 2012).

In this scenario, we proposed the hypothesis that progesterone might trigger ER stress and UPR, thus contributing to pancreatic $\beta$-cell death. Accordingly, we studied the expression of CHOP and CREB2 in RINm5F cells in response to progesterone and/or oestriol exposure. Progesteroneinduced CHOP protein expression increased in parallel to the hormone concentration up to ten times. Progesterone also increased the expression of CREB2 protein. Oestriol alone did not affect CREB2 expression; however, it slightly enhanced the upregulatory action of progesterone on RINm5F cells.

Published by Bioscientifica Ltd. 
Activation of caspases observed after incubation of RINm5F cells with progesterone indicates that the mechanism of progesterone-induced cell death is by apoptosis. In this study we showed activation of different caspases, but particularly of the executioner caspase 3 as well as of the mitochondrial caspase 9, and of the ER-stress-related caspase 12.

In summary, the present data indicate that progesterone induces apoptosis of insulin-producing cells in tissue culture and primary $\beta$-cells in rat pancreatic islets. As progesterone potently induced ROS formation and the toxic effect was antagonised by the antioxidant $\alpha$-tocopherol, it can be assumed that progesterone acts through a mechanism dependent on ROS generation, which may trigger ER stress and ultimately apoptotic cell death. Thus the results of this study provide new insights into the mechanisms underlying progesterone-induced death of $\beta$-cells, indicating that this hormone could contribute to development of GD when used under conditions where its use at pharmacological doses is recommended.

\section{Declaration of interest}

The authors declare that there is no conflict of interest that could be perceived as prejudicing the impartiality of the research reported.

\section{Funding}

This work was supported by Fundação de Amparo à Pesquisa do Estado de São Paulo - FAPESP (05607/2007).

\section{Acknowledgements}

The authors thank Dr Silvana Bordin for the valuable discussions.

\section{References}

Allagnat F, Fukaya S, Nogueira TC, Delaroche D, Welsh N, Marselli L, Marchetti P, Haefliger JA, Eizirik DL \& Cardozo AK 2012 C/EBP homologous protein contributes to cytokine-induced pro-inflammatory responses and apoptosis in $\beta$-cells. Cell Death and Differentiation 19 1836-1846. (doi:10.1038/cdd.2012.67)

Azevedo-Martins AK, Lortz S, Lenzen S, Curi R, Eizirik DL \& Tiedge M 2003 Improvement of the mitochondrial antioxidant defense status prevents cytokine-induced nuclear factor- $\kappa \mathrm{B}$ activation in insulin-producing cells. Diabetes 52 93-101. (doi:10.2337/diabetes.52.1.93)

Bradford MM 1976 A rapid and sensitive method for the quantitation of microgram quantities of protein utilizing the principle of protein dye binding. Analytical Biochemistry 72 248-254. (doi:10.1016/00032697(76)90527-3)

Butte NF 2000 Carbohydrate and lipid metabolism in pregnancy: normal compared with gestational diabetes mellitus. American Journal of Clinical Nutrition $\mathbf{7 1}$ 1256S-1261S.

Candolfi M, Jaita G, Zaldivar V, Zárate S, Ferrari L, Pisera D, Castro MG \& Seilicovich A 2005 Progesterone antagonizes the permissive action of estradiol on tumor necrosis factor- $\alpha$-induced apoptosis of anterior pituitary cells. Endocrinology 146 736-743. (doi:10.1210/en.2004-1276)

Cao SS \& Kaufman RJ 2012 Unfolded protein response. Current Biology 22 R622-R626. (doi:10.1016/j.cub.2012.07.004)

Cheng X, Shimizu I, Yuan Y, Wei M, Shen M, Huang H, Urata M, Sannomiya K, Fukuno H, Hashimoto Tamaoki T et al. 2006 Effects of estradiol and progesterone on tumor necrosis factor $\alpha$-induced apoptosis in human hepatoma HuH-7 cells. Life Sciences 79 1988-1994. (doi:10.1016/j.lfs.2006.06.044)

Contreras JL, Smyth CA, Bilbao G, Young CJ, Thompson JA \& Eckhoff DE $200217 \beta$-Estradiol protects isolated human pancreatic islets against proinflammatory cytokine-induced cell death: molecular mechanisms and islet functionality. Transplantation 74 1252-1259. (doi:10.1097/ 00007890-200211150-00010)

Dodd JM, Flenady VJ, Cincotta R \& Crowther CA 2008 Progesterone for the prevention of preterm birth: a systematic review. Obstetrics and Gynecology 112 127-134. (doi:10.1097/AOG.0b013e31817d0262)

Eizirik DL \& Cnop M 2010 ER stress in pancreatic $\beta$ cells: the thin red line between adaptation and failure. Science Signaling 3 pe7. (doi:10.1126/ scisignal.3110pe7)

Gurgul E, Lortz S, Tiedge M, Jörns A \& Lenzen S 2004 Mitochondrial catalase overexpression protects insulin-producing cells against toxicity of reactive oxygen species and proinflammatory cytokines. Diabetes 53 2271-2280. (doi:10.2337/diabetes.53.9.2271)

Gyamfi C, Horton AL, Momirova V, Rouse DJ, Caritis SN, Peaceman AM, Sciscione A, Meis PJ, Spong CY, Dombrowski M et al. 2009 The effect of 17-alpha hydroxyprogesterone caproate on the risk of gestational diabetes in singleton or twin pregnancies. American Journal of Obstetrics and Gynecology 201 392.e1-392.e5. (doi:10.1016/j.ajog.2009.06.036)

Jabs T 1999 Reactive oxygen intermediates as mediators of programmed cell death in plants and animals. Biochemical Pharmacology 57 231-245. (doi:10.1016/S0006-2952(98)00227-5)

Ito Y, Pandey P, Mishra N, Kumar S, Narula N, Kharbanda S, Saxena S \& Kufe D 2001 Targeting of the c-Abl tyrosine kinase to mitochondria in endoplasmic reticulum stress-induced apoptosis. Molecular and Cellular Biology 21 6233-6242. (doi:10.1128/MCB.21.18.6233-6242.2001)

Jayasooriva GS \& Lamont RF 2009 The use of progesterone and other progestational agents to prevent spontaneous preterm labour and preterm birth. Expert Opinion on Pharmacotherapy 10 1007-1016. (doi:10.1517/14656560902851403)

Kawai M \& Kishi K 1999 Adaptation of pancreatic islet $\beta$-cells during the last third of pregnancy: regulation of $\beta$-cell function and proliferation by lactogenic hormones in rats. European Journal of Endocrinology 141 419-425. (doi:10.1530/eje.0.1410419)

Le May C, Chu K, Hu M, Ortega CS, Simpson ER, Korach KS, Tsai MJ \& Mauvais-Jarvis F 2006 Estrogens protect pancreatic $\beta$-cells from apoptosis and prevent insulin-deficient diabetes mellitus in mice. PNAS 103 9232-9237. (doi:10.1073/pnas.0602956103)

Lenzen S 2008 Oxidative stress: the vulnerable $\beta$-cell. Biochemical Society Transactions 36 343-347. (doi:10.1042/BST0360343)

Lenzen S \& Bailey CJ 1984 Thyroid hormones, gonadal and adrenocortical steroids and the function of the islets of Langerhans. Endocrine Reviews 5 411-434. (doi:10.1210/edrv-5-3-411)

Lenzen S, Nahrstedt H \& Panten U 1983 Monoamine oxidase in pancreatic islets, exocrine pancreas, and liver from rats. Characterization with clorgyline, deprenyl, pargyline, tranylcypromine, and amezinium. Naunyn-Schmiedeberg's Archives of Pharmacology 324 190-195. (doi:10.1007/BF00503893)

Lortz S, Tiedge M, Nachtwey T, Karlsen AE, Nerup J \& Lenzen S 2000 Protection of insulin-producing RINm5F cells against cytokinemediated toxicity through overexpression of antioxidant enzymes. Diabetes 49 1123-1130. (doi:10.2337/diabetes.49.7.1123)

Matsumoto M, Minami M, Takeda K, Sakao Y \& Akira S 1996 Ectopic expression of CHOP (GADD153) induces apoptosis in M1 myeloblastic leukemia cells. FEBS Letters 395 143-147. (doi:10.1016/0014-5793 (96)01016-2) 
Momoi T 2004 Caspases involved in ER stress-mediated cell death. Journal of Chemical Neuroanatomy 28 101-105. (doi:10.1016/ j.jchemneu.2004.05.008)

Nakagawa T, Zhu H, Morishima N, Li E, Xu J, Yankner BA \& Yuan J 2000 Caspase-12 mediates endoplasmic-reticulum-specific apoptosis and cytotoxicity by amyloid- $\beta$. Nature $\mathbf{4 0 3} 98-103$. (doi:10.1038/47513)

Nguyen H \& Syed V 2011 Progesterone inhibits growth and induces apoptosis in cancer cells through modulation of reactive oxygen species. Gynecological Endocrinology 27 830-836. (doi:10.3109/ 09513590.2010.538100)

Nicoletti I, Migliorati G, Pagliacci MC, Grignani F \& Riccardi C 1991 A rapid and simple method for measuring thymocyte apoptosis by propidium iodide staining and flow cytometry. Journal of Immunological Methods 139 271-279. (doi:10.1016/0022-1759(91)90198-O)

Nieuwenhuizen AG, Schuiling GA, Liem SM, Moes H, Koiter TR \& Uilenbroek JT 1999 Progesterone stimulates pancreatic cell proliferation in vivo. European Journal of Endocrinology 140 256-263. (doi:10.1530/eje.0.1400256)

Nunes VA, Gozzo AJ, Juliano MA, Cerqueira César M, Sampaio MU, Sampaio CAM \& Araújo MS 2003 Antioxidant deficiency induces caspase activation in chick skeletal muscle cells. Brazilian Journal of Medical and Biological Research 36 1047-1054. (doi:10.1590/S0100879X2003000800010)

Nunes VA, Gozzo AJ, Cruz-Silva I, Juliano MA, Viel TA, Godinho RO, Meirelles FV, Sampaio MU, Sampaio CA \& Araujo MS 2005 Vitamin E prevents cell death induced by mild oxidative stress in chicken skeletal muscle cells. Comparative Biochemistry and Physiology C Toxicology \& Pharmacology 141 225-240. (doi:10.1016/j.cca.2005.06.001)

Oyadomari S \& Mori M 2004 Roles of CHOP/GADD153 in endoplasmic reticulum stress. Cell Death and Differentiation 11 381-389. (doi:10.1038/sj.cdd.4401373)

Pasanen S, Ylikomi T, Syvälä H \& Tuohimaa P 1997 Distribution of progesterone receptor in chicken: novel target organs for progesterone and estrogen action. Molecular and Cellular Endocrinology 135 79-91. (doi:10.1016/S0303-7207(97)00192-5)

Picard F, Wanatabe M, Schoonjans K, Lydon J, O'Malley BW \& Auwerx J 2002 Progesterone receptor-knockout mice have an improved glucose homeostasis secondary to $\beta$-cell proliferation. PNAS 99 15644-15648. (doi:10.1073/pnas.202612199)

Rao RV, Hermel E, Castro-Obregon S, del Rio G, Ellerby LM, Ellerby HM \& Bredesen DE 2001 Coupling endoplasmic reticulum stress to the cell death program: mechanism of caspase activation. Journal of Biological Chemistry 276 33869-33874. (doi:10.1074/jbc.M102225200)

Rebarber A, Istwan NB, Russo-Stieglitz K, Cleary-Goldman J, Rhea DJ, Stanziano GJ \& Saltzman DH 2007 Increased incidence of gestational diabetes in women receiving prophylactic $17 \alpha$-hydroxyprogesterone caproate for prevention of recurrent preterm delivery. Diabetes Care 30 2277-2280. (doi:10.2337/dc07-0564)

Reyes MR, Sifuentes-Alvarez A \& Lazalde B 2006 Estrogens are potentially the only steroids with an antioxidant role in pregnancy: in vitro evidence. Acta Obstetricia et Gynecologica Scandinavica 851090-851093. (doi:10.1080/00016340500453685)

Sanchez-Ramos L, Kaunitz AM \& Delke I 2005 Progestational agents to prevent preterm birth: a meta-analysis of randomized controlled trials. American Journal of Obstetrics and Gynecology 105 273-279. (doi:10.1097/01.AOG.0000150559.59531.b2)

Scaglia L, Smith FE \& Bonner-Weir S 1995 Apoptosis contributes to the involution of $\beta$-cell mass in the post partum rat pancreas. Endocrinology 136 5461-5468. (doi:10.1210/endo.136.12.7588296)

Scorrano L, Oakes SA, Opferman JT, Cheng EH, Sorcinelli MD, Pozzan T \& Korsmeyer SJ 2003 BAX and BAK regulation of endoplasmic reticulum
$\mathrm{Ca}^{2+}$ : a control point for apoptosis. Science $300135-139$. (doi:10.1126/ science.1081208)

Sen CK 1998 Redox signaling and the emerging therapeutic potential of thiol antioxidants. Biochemical Pharmacology 55 1747-1758. (doi:10.1016/S0006-2952(97)00672-2)

Straub SG, Sharp GW, Meglasson MD \& De Souza CJ 2001 Progesterone inhibits insulin secretion by a membrane delimited, non-genomic action. Bioscience Reproduction 21 653-666. (doi:10.1023/ A:1014773010350)

Sugaya A, Sugiyama T, Yanase S, Shen XX, Minoura H \& Toyoda N 2000 Expression of glucose transporter 4 mRNA in adipose tissue and skeletal muscle of ovariectomized rats treated with sex steroid hormones. Life Sciences 66 641-648. (doi:10.1016/S0024-3205(99)00636-0)

Tiedge M, Lortz S, Drinkgern J \& Lenzen S 1997 Relation between antioxidant enzyme gene expression and antioxidative defense status of insulin-producing cells. Diabetes 46 1733-1742. (doi:10.2337/diab. 46.11.1733)

Toyoda Y, Miyashita T, Endo S, Tsuneyama K, Fukami T, Nakajima M \& Yokoi T 2011 Estradiol and progesterone modulate halothane-induced liver injury in mice. Toxicology Letters 204 17-24. (doi:10.1016/j.toxlet. 2011.03.031)

Verma Y \& Rana SVS 2008 Effects of progesterone on benzene toxicity in rats. Archives of Industrial Hygiene and Toxicology 59 1-9. (doi:10.2478/ 10004-1254-59-2008-1835)

Wei T, Chen C, Hou J, Xin W \& Mori A 2000 Nitric oxide induces oxidative stress and apoptosis in neuronal cells. Biochimica et Biophysica Acta 1498 72-79. (doi:10.1016/S0167-4889(00)00078-1)

Wei MC, Zong WX, Cheng EH, Lindsten T, Panoutsakopoulou V, Ross AJ, Roth KA, MacGregor GR, Thompson CB \& Korsmeyer SJ 2001 Proapoptotic BAX and BAK: a requisite gateway to mitochondrial dysfunction and death. Science 292 727-730. (doi:10.1126/science. 1059108)

Welihinda AA \& Kaufman RJ 1996 The unfolded protein response pathway in Saccharomyces cerevisiae. Oligomerization and trans-phosphorylation of Ire1p (Ern1p) are required for kinase activation. Journal of Biological Chemistry 271 18181-18187. (doi:10.1074/jbc.271.30.18181)

Wu J \& Kaufman RJ 2006 From acute stress to physiological roles of unfolded protein response. Cell Death and Differentiation 13 374-384. (doi:10.1038/sj.cdd.4401840)

Xiang AH, Kawakubo M, Kjos SL \& Buchanan TA 2006 Long-acting injectable progestin contraception and risk of type 2 diabetes in Latino women with prior gestational diabetes mellitus. Diabetes Care 29 613617. (doi:10.2337/diacare.29.03.06.dc05-1940)

Yoshida H, Haze K, Yanagi H, Yura T \& Mori K 1998 Identification of the cis-acting endoplasmic reticulum stress response element responsible for transcriptional induction of mammalian glucose-regulated proteins, Involvement of basic leucine zipper transcription factors. Journal of Biological Chemistry 273 33741-33749. (doi:10.1074/jbc.273. 50.33741)

Zamzami N, Marchetti P, Castedo M, Decaudin D, Macho A, Hirsch T, Susin SA, Petit PX, Mignotte B \& Kroemer G 1995 Sequential reduction of mitochondrial transmembrane potential and generation of reactive oxygen species in early programmed cell death. Journal of Experimental Medicine 182 367-377. (doi:10.1084/jem.182.2.367)

Zhao H, Joseph J, Fales HM, Sokoloski EA, Levine RL, Vasquez-Vivar J \& Kalyanaraman B 2005 Detection and characterization of the product of hydroethidine and intracellular superoxide by HPLC and limitations of fluorescence. Proceedings of National Academy of Sciences USA 1025727 5732. (doi:10.1073/pnas.0501719102)

Received in final form 19 February 2014

Accepted 3 March 2014

Accepted Preprint published online 4 March 2014 http://joe.endocrinology-journals.org DOI: $10.1530 / J O E-13-0202$
() 2014 Society for Endocrinology Printed in Great Britain
Published by Bioscientifica Ltd. 